DOI https://doi.org/10.30525/978-9934-588-90-7-24

\title{
РОЗПОВІДНА ІНСТАНЦІЯ НАРАТОРА В «ОПОВІДАННІ ПРО СТЕПАНА ТРОХИМОВИЧА» МИКОЛИ ХВИЛЬОВОГО
}

\author{
Руденко М. I. \\ кандидат філологічних наук, \\ викладач кафедри украӥнської мови \\ Тернопільський національний медичний університет \\ імені І. Я. Горбачевського \\ Міністерства охорони здоров'я Украӥни \\ Мисик О. А. \\ кандидат філологічних наук, \\ викладач кафедри української мови \\ Тернопільський національний медичний університет \\ імені І. Я. Горбачевського \\ Міністерства охорони здоров'я Украӥни \\ м. Тернопіль, Украӥна
}

Серед самобутніх митців періоду «Розстріляного відродження» особливе місце належить Миколі Хвильовому. Розглядаючи його творчість поряд з модерністським у руслі авангардного мистецтва як засобу виявлення протесту проти метанаративних догм минулого, звертаємо увагу саме на наративну організацію його творів. Письменник засобами обраної ним розповідної стратегії у рамках художньої прози творить експеримент, який розгортається на кількох рівнях структури розповіді. Проблеми літератури і мистецтва письменник обговорює не тільки на шпальтах періодики чи у памфлетах періоду дискусії 19251928 років, але й у формі експліцитних виступів наратора своїх творів, руйнуючи таким чином стару традицію побудови розповіді.

Для здійснення наративного аналізу прози Миколи Хвильового була використана методика і типологія розповідних текстів Ж. Женетта, також методологічні та методичні напрацювання західних наратологів (Р. Барта, В. Бута, У. Еко, Ц. Тодорова) і російських дослідників розповідних текстів (І. Арнольд, М. Бахтіна, Н. Владімірової, Є. Добренко, І. Ільїна, Ю. Левіна, Ю. Лотмана, Ю. Манна, В. Руднєва, Б. Успенського).

Важливим теоретичним підгрунтям стали праці українських літературознавців В. Агєєвої, О. Білецького, Г. Грабовича, Р. Гром'яка, Т. Гундорової， М. Моклиці， В. Моренця, М. Наєнка, Д. Наливайка, 
С. Павличко, Л. Плюща, М. Рудницького, А. Ткаченка, М. Ткачука, Ю. Шереха, М. Шкандрія.

«Сказати, що оповідання розказане від першої чи третьої особи, означає не сказати нічого, якщо ми не станемо більш точними і не опишемо, як специфічні якості нараторів пов'язані із відповідним ефектом» [3, с. 146]. Цю тезу В.Бута можна вважати актуальною, коли звертаємося до аналізу особливостей гетеродієгетичного наратора в екстрадієгетичній ситуації, тобто розповідача першого рівня, котрий розповідає історію, де він відсутній як персонаж.

Специфіка наративного дискурсу художнього твору завжди позначена загальними засадами відношення між світом автора та світом героя, тобто «я»-суб’єктом наративного дискурсу та тим художнім світом, про який він розповідає у творі. Однак відповідно до структуральної поетики світи автора і героя експлікуються у тексті художнього твору на два комунікативні рівні. На рівні зовнішньої комунікації присутній реальний автор (М. Хвильовий) і читач - ми. Справжнім суб'єктом викладу в літературному творі $є$ наратор, тому, говорячи про відношення між світом автора і героя, маємо на увазі передусім відношення між рівнем наратора і персонажа. У цьому сенсі наратор $\epsilon$ фізичним, тобто текстуальним означником викладової концепції письменника, яка викристалізовується у його стосунках 3 уявним читачем.

«Оповідання про Степана Трохимовича» цілковито організовується постаттю наратора. За класифікацією Жерара Женета, це гетеродієгетичний наратор в екстрадієгетичній ситуації, який розповідає історію, в котрій він не виконує функції персонажа. Попри те, що він виступає в третій особі, присутність його явна і неприхована. Предметом розмови у творі $\epsilon$ постать старого робітника заводу Степана Трохимовича. В інтерпретації наратора його переживання спричинені віяннями нового часу, котрий вимагав активної суспільної позиції від кожного. Як це часто зустрічаємо в творах письменника, оповідач нерозривно прив'язаний до однієї постаті - головного персонажа.

Експліцитний автор організовує текст як літературний, що має п'ятнадцять частин і останній розділ «Замість епілогу». Кожний розділ має назву, що служить для збільшення дистанції між імпліцитним автором і читачем. Наївна позиція наратора виявляється у творенні цих заголовків, що досить поширені, розлогі, однак ніяк не висвітлюють закладеного автором у розділ змісту. Наприклад, 12-тий розділ має таку назву: «Подорож до Кліщевого двору. Які перешкоди зустріли Степана Трохимовича. Розмова $з$ жінкою. Куди потрапив старий коваль. Зустріч 3 місцевими вчителями: з Глушком і Митросенком» [2, с. 161]. Навіть заголовок оповідання має ще додатковий коментар: «мало не оповідання 94 
про те, як в кінці 1929 року Степана Трохимовича стривожив селянин Кліщ і як нарешті стривожений Степан Трохимович придбав собі помічника» $[2$, с. 100]. Наратор представляє наївний погляд на репрезентовані ним твори.

Завдяки дистанції між позицією автора i позицією наратора розкривається приховане ідейне навантаження тексту. Це оповідання можна розглядати як своєрідну соціальну концепцію. В його площині перехрещуються різноманітні точки зору на те, що відбувалося в молодій радянській республіці. Інертний Степан Трохимович насамперед хоче мати всі блага радянського функціонера, шану і повагу, і нічого для цього не робити. Його цілком задовольняє таке життя, і він не задається питанням, правильно це чи неправильно. Думки Степана Трохимовича оповідач передає за допомогою прямої мови і відтворює у вигляді транспонованого дискурсу. У власній же опінії він постає «революціонером»: «За револючіонера старий коваль завжди себе вважав. Правда, великих, заслуг за собою він ніколи не знав, але чи ж не він, скажімо, в тому ж таки 905 роиі виходив на барикади? Чи ж не він демонстрував зі своӥми товаришами по вулииях стривоженого міста? Правда, на барикадах йому не прийшлось битися (в той день сутички не було, а на другий - він поӥхав до Кармазинівки), але чи ж не його потім тягали по поліщейських участках?» [2, с. 104]. Однак до справжньої діяльності справа так і не доходить.

Розподібнення персонажів відбивається навіть на рівні їхнього мовлення. Онучка говорить дискантом, Кліщ «говорив тихеньким $i$ до того ж лагідним голосом. Щоправда, в иьому голосі завжди звучала якась неприємна глумлива нотка, але він ї̈ ніде і ніколи не підкреслював» [2, c. 115]. Не завжди в творі позиція наратора однозначна. Авторитетну характеристику Кліщеві дає саме наратор, де він стає на позиції імпліцитного автора. 3 тих же позицій і висловлюється оповідачем думка, яка від початку виникає у читача: Степан Трохимович « простує шляхом «моя хата скраю» [2, с. 120].

Цей же наратор подає читачеві відомості про Онучку, відбивши позицію наївного оповідача і знання імпліцитного автора. Розділ «Замість епілогу» тяжіє до резюмуючої розповіді. Експліцитний автор переказує, що сталося в Кармазинівці «історичного» 1930 року, як зазначає наратор, через три місяці після описуваних подій. Останній епізод, що теж цілком окреслений в часовому плані («зараз», «сьогодні»), можемо розглядати як момент написання твору. У такому випадку наратор переступає межі власної компетентності, оскільки вся розповідь ведеться так, як одночасна, тоді як з кінцівки видно, що мова велася про події, що вже відбулися. Наратор не претендував на всезнання, однак доступ до інформації мав. Оскільки найбільшу увагу він звернув на 
головного персонажа, то і поінформованість найбільша виявляється стосовно цього героя, все решта підпорядковане цій меті.

Отже, у творах М. Хвильового наявні різнокомпетентні наратори такий, що наближається до всезнання; з обмеженим знанням щодо зображуваної дійсності; оповідач, що об'єднує різні точки зору, або користується позицією одного персонажа. Немає лише стороннього спостерігача, що лише реєструє події. Кожне оповідання, новела, повість несуть на собі знаки наратора як найголовнішої інстанції у тексті, котрий ще й збудований з підкресленням того, що історія не відбувається, а розповідається або пишеться. Ступінь саморозкриття та самохарактеристики розповідача теж різна: від персоніфікованого, 3 власною біографією та естетичною концепцією, і до такого, що лише побіжно з'являється, однак залишається найбільш авторитетним джерелом оцінки внутрішньотекстових реалій.

Отже, вивчення художніх особливостей наративного дискурсу прози М. Хвильового дає можливість по-новому глянути на складний та суперечливий процес художньо-стильових шукань письменника.

3 одного боку, наратив письменника слід розглядати як вищу форму розвитку літературних тенденцій літератури попередніх періодів історико-літературного процесу, 3 іншого - спостерігаємо складний процес руйнування традицій літератури минулого. Йдеться, отже, про те, що наративний дискурс прози М.Хвильового розвивався на стику двох визначальних тенденцій літератури XX ст.: модерністської та авангардної. Перша у загальному контексті розвитку культури засвідчувала кінець попередньої епохи модерну, а друга - формувала зачин культури XX ст., тобто культури постмодерну, яка відзначається великим значенням категорії сумніву як центрального структуротвірного чинника. Отже, в наративі прози М.Хвильового можна означити особливості як літератури модернізму, так і літератури постмодерну, яка набуде свого розвитку пізніше.

\section{Література:}

1. Женетт Ж. Повествовательный дискурс. Фигуры. В 2-х томах. Т. 2. М. : Изд-во им. Сабашниковых, 1998. С. $60-280$.

2. Хвильовий М. Твори: У 2 т. Т.2 / Упоряд. М.Г. Жулинського, П. І. Майданченка. К.: Дніпро, 1990. 925 с.

3. Booth Wayn C. Types of Narration // Narratology: An Introduction / Edited and Introduced by Susana Onega and Jose Angel Garcia Landa. London New York, 1996. P. 146-154. 